\title{
CAN TRADITIONAL RETAILERS USE CONVENTIONAL STRATEGY TO FIGHT AGAINST MODERN RETAILERS ATTACKS?
}

\author{
Rachmadi Agus Triono ${ }^{1^{*}}$, Zuliani Dalimunthe ${ }^{2}$, Helman Arif ${ }^{3}$ \\ 1,2,3 Universitas Indonesia, Depok, Indonesia
}

\begin{abstract}
Despite rapid growth in online type, the majority Indonesian retail market is offline shopping because of households disperse across thousand cities and islands. However, the threat comes from corporatized modern retailers. Typically, attacks from modern retailers in the form of franchised minimarkets endangered the existence of traditional retailers which generally are small sized and independently owned by individual or household. This research investigates how traditional retailers can deliver a strategic response to the presence of modern retailers, and to examine whether there are differences in performance among business entities that use different strategic responses. We also investigate if there are differences, which strategic response would give the best result in performance. Questionnaires were distributed to 109 respondents using convenience sampling. An ANOVA was done at respective types of retailers' buyers. There is no significant evidence that the strategic response developed by traditional retailers differed from one another. Furthermore, we found that the performance of traditional retailers are below modern retailers, except for those that belong to a higher tier of performance. Higher tier traditional retailers are the best strategic group in traditional retailers and their performance statistically could equate to the performance of modern retail.
\end{abstract}

Keywords: Indonesian Retail Market, Small-Scale Retailer Strategy, Strategic Group, Strategic Response

\section{INTRODUCTION}

AT Kerney Global Retail Development Index (GDRI) 2016 placed Indonesia in 5th rank of top 30 developing countries for retail investment worldwide, a country has 256 million population and retail market worth USD 324 billion. Retail - and trading sector in general - is an essential sector of the Indonesian economy. The Central Bureau of Statistics (BPS) year 2018 report that trading sector contributes 13,1\% of Indonesian GDP in 2017 and absorb $18,57 \%$ of labor force.

Nowadays, retail sector worldwide facing the challenge from rapid rising in online shopping. However, the impact on offline shopping in Indonesia still unclear. Despite its significant growth, Indonesian retail market still dominated by offline shopping. Indonesian households are well dispersed over vast distances even islands. Consumer bases for the retail market outside main cities remain fragmented, especially in second and third-tier cities (Euromonitor report, 2018). It brings opportunity for offline retailers to continue their business in Indonesia and maintain their consumers.

Unfortunately, the huge of Indonesian retail market brings another challenge for traditional retailers. Indonesia Retail Entrepreneur Associations

* Corresponding author. Email address: Rachmadi78@gmail.com 
(APRINDO) divide the retail market into a modern retailer and traditional retailer. The growth of modern retail has increased significantly over time but mainly from franchised minimarkets having brand developed by big corporations. They directly attack traditional retailers generally small and informally-managed. From 2002 until now, attack from franchised minimarkets on traditional retail increased significantly. Franchised minimarkets are continuing to grow from major cities to second or third layer cities even to villages throughout Indonesia.

Modern retailers in Indonesia commonly organized and owned by big corporations. Meanwhile, traditional retailers generally small and independently owned by individual or households with limited capital (Praharsi et al., 2014). AC Nielsen in Retail Audit (2010) provide evidences how declining in traditional retail markets as the result of franchised minimarket attacks. From macroeconomic perspectives, declining share of traditional retailer market compares to modern retailers affect to the lower purchasing power of households relied on this sector. Increasing growth in modern retailers and declining in traditional retailers bring negative consequences on national objectives to reduce income gap and even to alleviate poverty also.

Indonesian traditional retailers need strategic competitiveness to continue in the market. At least they need to respond strategically on the continuing attack from modern retailers. This study aims to evaluate how Indonesian traditional retailers strategically respond to modern retailer attacks. The results of this study should offer solutions for traditional retailers in how to deal with these attacks. Indirectly, by doing this research, we also want to recommend government how to increase labor force purchasing power working in the traditional retail sector.

We tested four hypotheses in this research. Firstly, minimarkets as franchise business entities have three prime advantages -size, system, and skillscompared to traditional retail. Thus, its performance should be higher than the traditional retail market. Secondly, different traditional retail groups will develop different strategic responses, and they will develop similar strategic responses within the traditional retailer group. Thirdly, strategic competitive response in various strategic groups associated with the strategic group's performance. And lastly, the strategic competitive response in the best group could result in comparable performance to minimarkets.

This paper consists of six parts. After introduction part, literature study provides in the second part, consist of the concept of retailers, strategy and competitive responses, business performance and hypothesis development. The third part consists of data and methods used in this study. The fourth part provide results of the study while the fifth discuss the results along with similar research conducted in other country. The last part consists of conclusion and implications as well as limitation of the study.

\section{LITERATURE STUDY AND HYPOTHESES DEVELOPMENT 2.1. Retail Definition}

According to Berman and Evans (2001) retail is business activities that sell goods and services to end customers that buy the products for their personal use. They explain further: 
Selling are made in a small amount, just enough to be used for personal consumptions in a specified time. Types of buying are impulse buying, as an opposite of rational buying where the customer buy without deeper rational considerations. When buying, customers consider business location, product handling effectivity, store opening hours, and price level.

Meanwhile, Levy and Weitz (2012) define retailing with emphasize more on activities that create value added to goods and services sold both for personal or family use. Furthermore, Sujana (2005) classified retail according to its ownership, merchandise category and the breadth of the outlet. According to ownership, he classified retail to single store retailer, company-owned retailer, and franchise store which built based upon a cooperative contract between brand owner as a franchisor and outlet owner as the franchisee. Sujana (2005) then classified retailers by outlet's breadth as small store (less than $100 \mathrm{~m} 2$ ), minimarket $(100 \mathrm{~m} 2-1.000 \mathrm{~m} 2)$, supermarket $(1.000 \mathrm{~m} 2-5.000 \mathrm{~m} 2)$ and hypermarket (more than $5.000 \mathrm{~m} 2$ ).

Praharsi et at (2014) divided Indonesian retailer into two board category, namely organized retailer and small-independent retailers. Organized retailer defined as large-scale chain stores that are corporatized while smallindependent retailers are a single store, sole-proprietorships and own by individual or family. In their study, organized retailers typically refer to Indomaret and Alfamart widely known in Indonesia due to their rapid expansion nationwide in short period of time and directly threatening the existence of small-independent of traditional retailers.

In this study, we define traditional retails as those retail owned by an individual (single store retailers) with outlet area less than $100 \mathrm{~m} 2$. Meanwhile, minimarkets are defined as franchised outlet of nationwide brands with space between $100 \mathrm{~m} 2-1.000 \mathrm{~m} 2$. Both retail stores with brand Indomart and Alfamaret are included in this definition.

\subsection{Strategy and Competitive Response}

Porter (1985) defined strategy as the effort to place a company position as a unique entity and increase its value through effective decisions. While Kluyver and Pearce (2005) described strategy as an effort to position a company to gain competitive advantage through the choice of industry entered, product decisions, and allocating resources. Furthermore, Rumelt (2011) define a strategy based on a structure as a "kernel", which has three elements: (1) diagnosis on the situation faced; (2) guiding policy to meet challenges; and (3) coherent activities to apply the guiding policy.

The concept of strategy broadly used by settled businessmen with large businesses, but the concept is applicable to retail business also. Levy and Weltz (2012) stated that retailers had used the idea of strategy as a plan that focused on resources to achieve their goals and the creation of relative competitive advantage as compared to the competitors. Typically, strategic plan in retail business conducts through target market identification, and deliver goods and services fit to target markets or consumers. The creation of competitive advantage of a retailer performed through several generic strategies - according to Porter (1985) - consist of sales services and product differentiations, price leadership, and the combination of low cost and differentiations (Ramakrishnan, 2010). 
Competitive response, on the other hand, is a counteraction toward competitors to gain market position, and those actions describe interactions among companies within an industry. Grimm et al. (2006) stated that competitive response is a source of competitive advantage and, hence, the ability to gain a better profit. Thus, traditional retailers need strategies representing competitive responses to modern retailer actions. An appropriate competitive response would increase the competitive position of a traditional retailer.

In the context of group action to fight against their competitors, there is a theory of strategic groups. The theory predicts that existence of a specific group in business entities occur due to convergent behaviour of such entity in respond to its environment (Halaj \& Zochowski, 2009). A business entity employed a specific combination of strategic response identified itself as a member of a strategic group. Gamble and Thompson (2011) define a strategic group as a group of companies in an industry having similar competitive approach and competitive position. The similarity can be in the form of same product variety, selling price, distribution channels, or similarity in services. At a certain level, it proved that specific strategic responses are effective through confirmation of business performance. Furrer et al. (2008) showed that the chosen strategy determines the performance of a business entity. Hence, one can say that to make a business entity as a place to go shopping, the entity should choose a combination of strategy or strategic response to its opponents.

\subsection{Business Performance}

The concept of business performance has pros and cons in business research. This issue isn't so much about how to measure, but rather what is to be measured (Matthews, 2011). The measures of objective performance include accounting performance and market performance. However, researchers in strategic management have a difficult time obtaining objective measures of performance (Dess \& Robinson, 1984). Thus, there are so many researchers employed business performance measurement through what is called subjective self-reporting (Beal, 2000). The use of subjective performance measurements will not reduce the quality of the research, however. Wall et al. (2004) reported a high degree of reliability and validity from subjective business performance in their research. Finally, the relationship between generic strategy used and performance has been reported by Acquaah and Ardekani (2008) and Amoako and Acquaah (2008).

\subsection{Hypothesis Development}

This research aims to examine whether performance of traditional retailers grouped in strategic groups is equal or worse compared to minimarket retailers. Minimarket has ten determinants supposed to be superior than traditional retailers. Hansen and Wernerfelt (1989) stated three factors making the performance of a business entity differentiate. They are size, system and skill. Other determinants are economies of scale and experiences (Douglas \& Donald, 1969), influence of technology (Morgenstein and Harriet, 1992); location and property (Guy, Clifford, 1994); retail market strategy (Michael and Barton, 2004); as well as employee satisfaction orientation, merchandises, product lines, and square feet of store space (Robbins, Stephen P, 2005; Tang and Lim, 2004). For all those ten determinants, minimarket retailers have competitive advantage than traditional retailers. Thus, first hypothesis could be stated as follows: 
Hypothesis 1:

"Minimarket retailer's performance should be higher than traditional retailers".

About strategic groups developing different strategic response, Porter (1979) said that: "An industry can be viewed as composed of clusters or groups of firms where each group consists of firms following similar strategies regarding key decision variables...... I define such groups as strategic groups."

A similar strategy here is defined as a combination of strategy adopted by traditional retailers to fight against modern minimarkets' attack in their respective regions. Different minimarket strategies in their respective area will result in different strategic responses developed by traditional retailers in their region to face their respective minimarket retailers. It means that in a specific region, all traditional retailers facing the same minimarket attack will develop similar strategic responses while in different minimarket locations, the respective traditional retailers will develop different strategic responses. Had all the traditional retailers in one region are considered as one strategic group, and in others that face others minimarket are regarded as separate strategic groups, then it would be expected that in one strategic group the traditional retailers will develop similar strategic responses that differ with developed by other strategic groups. Thus, the second hypothesis could be stated as:

Hypothesis 2:

"Different traditional retail groups will develop different strategic responses, and similar strategic responses will be developed within a traditional retailer group".

To the extent of traditional retail group performance concern due to the strategic response developed, should be proven with its ability to achieve more either to its opponent-minimarket- or to its others strategic groups fellow. As has been said, Furrer, et al. (2008) proved that business entity's performance is determined by its strategic choice either resources or generic strategic choice. The stand-alone relationship between performance and resources choices have been proven by Delios and Beamish (2001,2017), Kraatz and Zajac (2001), Vorhies and Morgan (2003) and Kor and Mahoney (2005). On the other hand, a relationship between generic strategy and performance, as stated before, has been proven by Acquaah dan Ardekani (2008), as well as Amoako and Acquaah (2008). Hence, the third and fourth hypothesis can be stated as follows:

Hypothesis 3:

"Strategic competitive response in respective strategic groups associated with the strategic group's performance." 
Hypothesis 4:

"Strategic competitive response in the best group is comparable to performance of minimarket retailers."

\section{RESEARCH METHODOLOGY}

\subsection{Data}

This research use customer's perceptions to measure variables used in the research toward traditional retailers and minimarkets, namely their respective strategic response and performance. The data gathered in Depok, Indonesia using the convenience sampling method, while the determination on the number of respondents was calculated using the statistical method developed by Cochran (1963). In this research, we determine a quota of 100 respondents. When applied, it is composed of 109 respondents quoted proportionally in four Depok regions: Beji, Cinere, Sukmajaya and Kukusan, which represent both rural areas (Beji and Kukusan) and urban areas (Cinere and Sukmajaya).

\subsection{Variables Operationalization}

In this research, conventional retail strategy is defined as a series of action taken by retailers to make their stores become more preferred place to go shopping. Such actions including various sales services, availability of highquality goods, purchases in small quantities, diversity of products sold, customer relationships, convenience purchases, credit facility, discounts, and lower prices.

'This research used the cluster elements (Xi) suggested by Porter (1985), which is a translation of the five strategic response dimensions consist of product orientation (X1), selling price (X2), sales services (X3), cost focus (X4), and technological orientation (X5). The selling price indicators, according to Ramakrishnan (2010), are selling price below the competitors' and selling products at a lower price. Megicks (2001) contributed one indicator: give discounts in response to the modern minimarket strategy.

The elements of cluster $\mathrm{Xi}$ by which clusters formed are strategic responses of traditional retailers and minimarkets, respectively. Another dimension of strategic response is sales services, namely all services given, convenience, gifts, and easy to purchase. Megicks (2001) said that employee training to increase courtesy while serving their customers is an indicator of sales service directed toward opponents' strategies. Ramakhrisnan (2010) added three indicators: convenience when purchasing, home delivery service, and giving special attention to the needs of customers. The cost focus strategy while maintaining product quality was stated by McGee and Rubach in Ramakrishnan (2010), and specifies two elements: give a discount on the total amount of purchase and give gifts through overhead efficiency. The technological orientation element was suggested by Ramakrishnan (2010). He suggested two indicators: the use of computers for sales and administration, and payment using credit cards. Finally, the performance of a business entity is measured using subjective performance indicators composed of customers' subjective assessments toward the outlet.

Those latent variables dimension, are further operationalized into several indicators, and each is assigned using five scales Likert ratings ( $1=$ strongly disagree. $2=$ disagree. $3=$ neither disagree nor agree. $4=$ agree. $5=$ strongly agree) 
to express respondents' subjective assessment on each indicator. The use of these subjective assessments by no means reduce the quality of research findings since it has been found that there is a closed correlation between subjective performance and objective performance measurements (Voss and Voss, 2000). Another researcher, Megicks (2001), suggested the whole store success indicator.

\section{RESULTS}

We examine the research instrument validity before testing hypothesis through factor analysis. Validity defined as whether a measurement able to measure what it intends to measure (Suter, 2006). The element of each strategy or strategic response together with aspects of performance were processed using factor analysis with varimax rotations. Several operational variables in each strategic dimension do not valid and hence deleted from each corresponding operational variable. However, all operational variables are valid to use as definitions for each latent variable, as shown by their high factor loading's values. After these not valid operational variables omitted, latent variables namely Product Orientation, Selling Price, Services, Cost Focus and Quality, Technology Orientation and Performance have six, five, ten, eight, five and five operational variables respectively. The result shown in Table 1 together with each respective factor loadings.

Table 1 Principal component factor analysis with varimax rotation of retail strategic response

\begin{tabular}{|c|c|c|c|c|c|c|}
\hline \multirow{2}{*}{$\begin{array}{c}\text { Strategic } \\
\text { Dimension }\end{array}$} & \multicolumn{6}{|c|}{ Factor Loadings } \\
\hline & Product & Price & Services & Cost & Technology & Performance \\
\hline Product1 & 0.645 & & & & & \\
\hline Product2 & 0.681 & & & & & \\
\hline Product3 & 0.772 & & & & & \\
\hline Product5 & 0.652 & & & & & \\
\hline Product6 & 0.667 & & & & & \\
\hline Product15 & 0.607 & & & & & \\
\hline Price1 & & 0.740 & & & & \\
\hline Price2 & & 0.553 & & & & \\
\hline Price3 & & 0.802 & & & & \\
\hline Price4 & & 0.828 & & & & \\
\hline Price5 & & 0.703 & & & & \\
\hline Service13 & & & 0.633 & & & \\
\hline Service14 & & & 0.688 & & & \\
\hline Service22 & & & 0.616 & & & \\
\hline Service24 & & & 0.745 & & & \\
\hline Service25 & & & 0.798 & & & \\
\hline Service26 & & & 0.748 & & & \\
\hline Service27 & & & 0.778 & & & \\
\hline Service32 & & & 0.569 & & & \\
\hline Service33 & & & 0.597 & & & \\
\hline Service40 & & & 0.623 & & & \\
\hline Cost1 & & & & 0.812 & & \\
\hline Cost2 & & & & 0.897 & & \\
\hline Cost3 & & & & 0.822 & & \\
\hline
\end{tabular}




\begin{tabular}{|c|c|c|c|c|c|c|}
\hline \multirow{2}{*}{$\begin{array}{c}\text { Strategic } \\
\text { Dimension }\end{array}$} & \multicolumn{6}{|c|}{ Factor Loadings } \\
\hline & Product & Price & Services & Cost & Technology & Performance \\
\hline Cost4 & & & & 0.861 & & \\
\hline Cost5 & & & & 0.857 & & \\
\hline Cost6 & & & & 0.714 & & \\
\hline Cost7 & & & & 0.860 & & \\
\hline Cost8 & & & & 0.798 & & \\
\hline Techno1 & & & & & 0.898 & \\
\hline Techno2 & & & & & 0.943 & \\
\hline Techno3 & & & & & 0.660 & \\
\hline Techno4 & & & & & 0.943 & \\
\hline Techno5 & & & & & 0.894 & \\
\hline Perform2 & & & & & & 0.666 \\
\hline Perform3 & & & & & & 0.829 \\
\hline Perform4 & & & & & & 0.662 \\
\hline Perform5 & & & & & & 0.874 \\
\hline Perform6 & & & & & & 0.803 \\
\hline
\end{tabular}

Latent variable 1 (Product Orientation) measured by selling durable goods (product1), selling goods in good condition (product2), excellent packaging (product3), products sold are fresh (product5), and having good looking (product15). Latent variable 2 (Selling Price) measured by lower price (price1), some products are cheaper (price2), the price is low (price3), cheaper than other stores (price4) and the prices are negotiable (price5). Latent variable 3 (Services) emphasizes on self-services (serrvice13), pleasant store layout (service14), goods are always available (service22), store keepers answer question quickly (service 24), store keepers answer question in good manners (service 25), store keepers answer question perfectly (service26), store keepers answer any question (service27), goods can be delivered to consumer's house (service 32), products can be delivered even for some specific amount (service33), and customer able making order to the store (service40). Variable 4 (Cost Focus and Quality) refer to responses emphasizing in discount provided by the store (cost1), discounts provide even for specified amount of purchase (cost2), discount provided for some certain product (cost 3$)$, the store provide gift for some purchases (cost4), gifts deliver directly (cost5), gifts are still deliver even indirectly (cost6), gifts delivered even for purchase in some specific amount only (cost7) and the customer received a gift for purchasing specific product only (cost8). The last strategic response variable is Technological Orientations consist of using computer for transaction processing (techno1), using computer for merchandise and inventory processing (techno2), the payment for purchasing easily accomplish (techno3), credit cards are acceptable (techno4), and debit cards are acceptable (tehno5).

Meanwhile, Store Performance variables consist of popularity of the store (performance2), the store always full of visitors (performance3), the store size increasing overtime (performance4), buyers increase from time to time (performance5) and the merchandises offered increase from time to time (performance6).

Next, to test the construct reliability, we measure the Cronbach alpha index (Cronbach, 1951) as shown in table 2 below. The index measures internal 
consistency of the research instrument used, that is how a set of items closely related as a group. The alpha index is viewed as the expected correlation among operational variables measuring the same construct.

Tabel 2 Construct Reliability Measurement of Modern Retail and Traditional Retail

\begin{tabular}{cccc}
\hline Variable & Indicators & $\alpha$ modern & $\alpha$ traditional \\
\hline Product Orientation & 6 & 0.649 & 0.836 \\
Selling Price & 5 & 0.843 & 0.819 \\
Sales Services & 10 & 0.843 & 0.890 \\
Cost focus \& quality & 8 & 0.939 & 0.935 \\
Techno orientation & 5 & 0.855 & 0.922 \\
Business Performance & 5 & 0.714 & 0.812 \\
\hline
\end{tabular}

As seen in Table 2 above, all Cronbach alpha's indexes are above 0.6, proving that the internal reliability of instruments used are strong. It means that all respondents have similar perceptions on the meaning of variables used. Thus, instruments used in the study is not bias. Furthermore, the testing hypothesis using ANOVA and cluster analysis of the four hypotheses are shown in Table 3.

Table 3 Testing Null Hypothesis

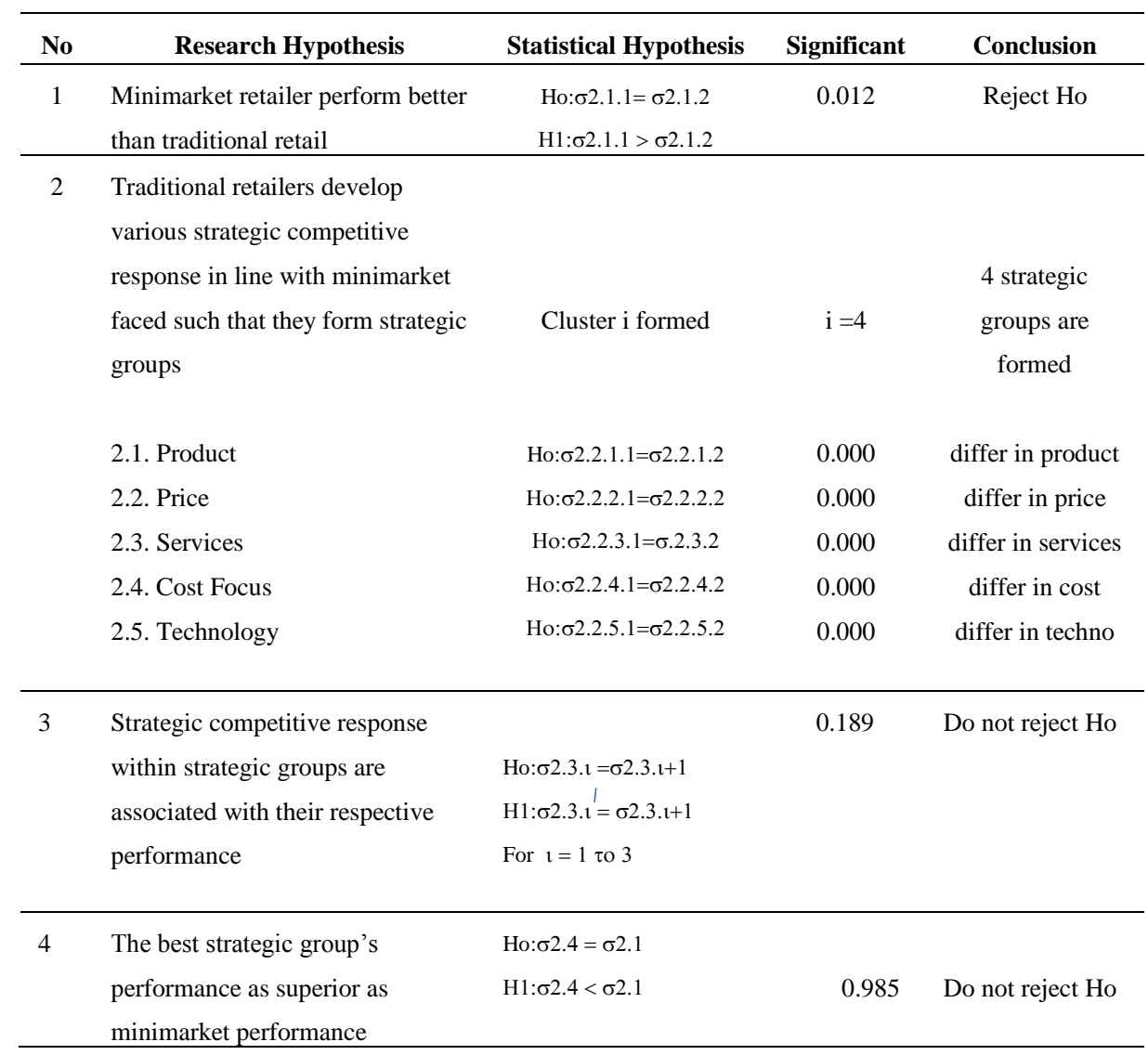

From Table 3 above, we generate four conclusions. Firstly, performance between minimarkets and traditional retailers is different. The performance of minimarkets outperforms the traditional retail markets. Secondly, the traditional retailers developed strategic competitive responses in line with minimarkets, such that they formed strategic groups. The strategic dimensions used are significantly different between the four groups formed. Thirdly, there are no 
performance differences among the strategic groups concerning the strategic response, meaning that the strategic response does not associate with performance. Fourth, there is no best strategic groups with its respective associated strategic response that differs in performance with the minimarket, which means that there are no superior strategic responses that lead to an excellent performance.

\section{DISCUSSION}

From the first fact we conclude that minimarket had already disturbed traditional retailers' market performance. It means that two entities - the traditional retailer and the minimarkets - have the same market and are not separated by location, effort, or other separation dimensions. They are perfect competitors in the marketplace. Then, logical result of the first null hypothesis test prove that competitive responses are essential for traditional retailers to do. It is also proven by the fact that from the four clusters formed (Table 4), the strategic response used by each cluster consist of a combination of technological response, hard/soft services, and services oriented toward products. Four clusters formed here is slightly different to what Ramakrishnan (2010) did in his study in India. His study results in 5 clusters strategic group. Four of which just the same to what this study got, together with the fifth strategic group named traditional.

A deeper analysis directed toward strategic competitive response used by the four strategic groups of traditional retail show that Strategic Group 1, the competitive, uses all dimension of strategic responses in an equally balanced manner. With relatively high investment in technology, it results in better performance than those of misdirected and middle of the road cluster strategic groups.

Strategic Group 2, the misdirected, is just like strategic group 1 except that their service and cost focus \& quality dimensions are lower. It also does not invest much in technology. While it trying to address a broad target through product variety and pricing strategy, it performance result is the lowest among the other strategic groups formed.

Table 4 Final Cluster of Strategic Group formed

\begin{tabular}{|c|c|c|c|c|}
\hline Strategic & Cluster1 & Cluster2 & Cluster3 & Cluster4 Full \\
\hline Response & $\begin{array}{l}\text { Competitive } \\
\mathrm{n}=30\end{array}$ & $\begin{array}{l}\text { Misdirecte } \\
\mathrm{d} \quad \mathrm{n}=19\end{array}$ & $\begin{array}{l}\text { Mid of the } \\
\text { road } n=32\end{array}$ & Service $n=28$ \\
\hline Product & 3.7 & 3.5 & 3.3 & 4.4 \\
\hline Price & 3.6 & 3.4 & 3.3 & 3.9 \\
\hline Services & 3.6 & 2.8 & 3.1 & 4.0 \\
\hline Cost & & & 2.8 & \\
\hline Quality & 3.5 & 1.6 & 2.8 & 3.8 \\
\hline Technology & 2.8 & 2.4 & 2.4 & 4.2 \\
\hline Performance & 4.5 & 4.2 & 4.3 & 4.7 \\
\hline
\end{tabular}

Strategic Group 3 uses all the dimensions of strategic responses in equally balanced manner just as group 1, but they use smaller amounts as compared to other clusters, which resulted in a mediocre result.

While Strategic group 4 uses all strategic responses in highest amount than other groups, in attempt to reach both niche customers and those of price 
sensitive segments. With these strategies this strategic group yield in the best performance indicator among the groups formed.

Although the data does not suggest a significant mean difference of the performance dimension of four strategic groups formed, it is apparent that Strategic Group 4 outperformed the other strategic groups.

Contrasting to what Ramakrishnan (2010) revealed from traditional retail in India to what comparable traditional retail in Indonesia discuss in this research, one can see that in all comparable clusters, traditional retail in India used the element of technology higher than its allied retail in Indonesia (Table 5). This difference could be caused by the fact that India has more advance in technological development as compared to Indonesia. A popular thesis is that Indonesia lags five years behind and that we'll see it follow a similar technological development trajectory (Freischlad, Nadine: 2016). India's traditional retail also have higher score of Cost Focus and Quality as compared to its peer in Indonesia. The root of this difference could be attributable to Indonesia's retailer culture that demand high profitability at the cost of the buyer in the form of lower product quality. For instance, the viral habit of Indonesian food sellers to use synthetic dyes and artificial sweeteners in their merchandises sold (Priambodo, RA, 2016)

On the other hand, traditional retail in Indonesia tend to use service elements better as their strategic response than its associates traditional retail in India. They also use elements product and pricing better in four clusters strategic group formed. No wonder, Indonesia is an archipelagos known for its hospitality.

Table 5 Comparison of strategic responses used by traditional retail in Indonesia and India

\begin{tabular}{lcccc}
\hline $\begin{array}{c}\text { Strategic } \\
\text { Response }\end{array}$ & Competitive & Misdirect & $\begin{array}{c}\text { Mid of the } \\
\text { road }\end{array}$ & $\begin{array}{c}\text { Full } \\
\text { Service }\end{array}$ \\
\hline Products & 3.71 & 3.51 & 3.30 & 4.36 \\
& $\mathbf{4 . 0 0}$ & $\mathbf{4 . 0 0}$ & $\mathbf{3 . 0 0}$ & $\mathbf{4 . 0 0}$ \\
Pricing & 3.63 & 3.39 & 3.30 & 3.92 \\
& $\mathbf{3 . 3 0}$ & $\mathbf{2 . 9 0}$ & $\mathbf{3 . 2 0}$ & $\mathbf{4 . 3 0}$ \\
Services & 3.63 & 2.76 & 3.10 & 4.02 \\
& $\mathbf{2 . 7 9}$ & $\mathbf{2 . 1 5}$ & $\mathbf{3 . 1 5}$ & $\mathbf{3 . 9 8}$ \\
Cost Focus \& & 3.46 & 1.64 & 2.80 & 3.76 \\
quality & $\mathbf{4 . 0 0}$ & $\mathbf{2 . 0 0}$ & $\mathbf{3 . 0 0}$ & $\mathbf{4 . 0 0}$ \\
Technology & 2.81 & 2.39 & 2.40 & 4.20 \\
& $\mathbf{3 . 0 0}$ & $\mathbf{3 . 2 0}$ & $\mathbf{3 . 4 6}$ & $\mathbf{4 . 2 4}$ \\
\hline
\end{tabular}

Source: Comparison between Table 4 and Ramakhrisnan (2010)

*Bold figures are result in India

Although the test of null hypothesis of hypothesis 1 result in the null hypothesis rejection, means that minimarket has superior performance than traditional retails. Looking deeper into performance indicators differences between the traditional market and the modern retail market as shown in Table 6 , one can see that some of the traditional retailer's performance indicators can equate the minimarket indicators. For instance, indicator 4 (space increment of the retail entity) and performance indicator 6 (increment of merchandise sold by the retail body) are not significantly different between the two entities. It is 
true that this fact can be interpreted that both, the traditional retail and minimarket are never increase their space store and the variety of merchandise sold, but the interpretation that they grow in similar rate can speculatively, also be considered. Meanwhile, indicator 2 (the retail entity is widely known), indicator 3 (the store is always crowded), and indicator 5 (buyers increase from time to time) show that modern minimarkets are outperforming the traditional retail market. Apparently, these 3 performance indicators that responsible for the higher performance score value of minimarket as compared to traditional retailers.

Table 6 Performance Difference between Traditional and Modern Retail

\begin{tabular}{ccll}
\hline Indicator & \multicolumn{1}{c}{ F } & Significant & \multicolumn{1}{c}{ Conclution } \\
\hline Performance2 & 10.055 & 0.002 & Differ \\
Performance3 & 7.569 & 0.006 & Differ \\
Performance4 & 0.610 & 0.805 & Do not differ \\
Performance5 & 11.056 & 0.001 & Differ \\
Performance6 & 1.960 & 0.163 & Do not differ \\
\hline
\end{tabular}

The use of integrated strategic response, indicate superior result as competitive advantage builder in traditional retailer. This is consistent with the finding of Ramakrishnan (2010), although the result of the study is statistically not significant. However, the research result could point out to those who plunged into the retail business to implement such strategy as the strategic response to their minimarket opponents.

Focus differentiation strategy as operationalized through the exercise of product variability should be mixed with Cost \& quality to get excellent result unless it throws out into misdirected and middle of the road strategic cluster with poor performance result

\section{CONCLUSION}

This research's objective is to find whether traditional retailers develop different strategic responses depending on minimarkets faced, and then to discover which strategic responses achieve the best performance against attacks from the franchise minimarkets. We found that the data do not support all the research hypotheses. They also do not reject all the null hypotheses. The analysis proves that although the traditional retailers created four types of strategic response within four cluster strategic groups, the differences among the responses are hard to identify since all the responses were composed of similar elements of strategic response combinations, though they all differed in dimension.

From the analysis, we also identified that the performance of traditional retailers does not differ significantly among the three strategic groups. However, it can still be seen that there is one strategic response that best led to superior performance when facing attacks from modern minimarkets, i.e., using all the strategic dimensions as a strategic response.

The implication of such findings is that modern retail markets are going head-to-head with traditional retailers in the market. Their customers could not be partially or fully separated. They steal customers back and forth from each other. That is why both traditional retailers and modern retailers do not grow independently without comparable performance growth. Dealing with such 
situations, therefore, would require the development of strategic responses by traditional retailers to their opponent - which is the modern retail entities, by exploiting the strategic response dimension that best fits to combat their modern supermarket opponent.

This study has two limitations. First, the study was done only in one medium city in Indonesia, both rural and urban area. Even the generalizability of the study does not limited by rural-urban considerations, it is bounded by the sampling distribution agenda. In the future, such study in Indonesia should cover more cities as research area. Another limitation is in the selection of respondents. It seem to me that interviewers select respondents too freely, ignoring the size of traditional store that is chosen. Thus, even a very small store might be selected when interviewing their buyers as respondents. However, that kind of store tend to neglect the important of strategic response, so that the respondents -their buyers- perceive as such.

\section{References}

AC Nielsen. (2010). Retail Audit, unpublished.

Acquaah, M., \& Ardekani, M. Y. (2008). Does the implementation of a combination competitive strategy yield incremental benefit? A New Perspective fom a transition economy in Sub Saharan Africa. Journal of Business Research, 61(4), 346-354.

Amoako-Gyampah, K., \& Acquaah, M. (2008). Manufacturing strategy, competitive strategy, and firm performance: An empirical study in developing economy environment. Journal of Production Economics, 111(2), 575-592.

Beal, R. M. (2000). Competing effectively: Environmental scanning, competitive strategy, and organisational performance in small manufacturing firms. Journal of Small Business Management, 38(1), 2747.

Berman, B., \& Evans, J. R. (2001). Retail Management: A Strategic Approach. New Jersey: Prentice Hall.

Cochran, W. G. (1963). Sampling Techniques $2^{\text {nd }}$ Ed. New York: John Willey and Sons, Inc.

Conant, J. S, Smart, D. T., \& Mendez, S. R. (1993). Generic Retailing Types, Distinctive Competencies, and Competitive Advantage. Journal of Retailing, 69(3), 254-279.

Cronbach, L. J. (1951). Coefficient alpha and the internal structure of tests. Psychometrika, 16, 297-334.

Dess, G.G., \& Robinson R. B. Jr. (1984). Measuring organizational performance in the absence of objective measures: The case of the privately-held firm and conglomerate business unit. Strategic Management Journal, 5(3), 265-273. 
Delios, A., \& Beamish, P. W. (2001,2017). Survival and profitability: the roles of experience and intangible assets in foreign subsidiary performance. Academy of Management Journal, 44(5 ).

Douglas, J. D., \& Donald, L. T. (1969). Retailing: an economic overview. New York: Free Press.

Furrer, O. D., Sudharshan, H. T., \& Maria, T. A. (2008). Resource configurations, generic strategies, and firm performance: Exploring the parallels between resource-based and competitive strategy theories in a new industry. Journal of Strategic Management, 1(1), 15-40.

Freischlad, N. (2016). India Vs Indonesia: how investors like sequoia think about it. www.techinasia.com

Gamble, J., \& Thompson, A. A. (2011). Essentials of Strategic Management. Mc Graw Hill

Grimm, C. M., Lee, H., \& Smith, K. G. (2006). Strategy as action: Competitive dynamics and competitive advantage. Oxford University Press.

Guy, C. (1990). The retail development process: location, property and planning, London and New York.

Halaj, G., \& Zochowski, D. (2009). Strategic group and bank's performance. Financial Theory and Practice, 33(2), 153-186.

Hansen, G. S., \& Wernerfelt, B. (1989). Determinants of Firm Performance: The relative important of Economics and organizationals Factors. Strategic Management Journal, 10(5), 399-411.

Kluyver, C. A. D., \& Pearce, J. A. (2005). Strategy: View from the top. Prentice Hall.

Kor, Y. Y., \& Mahoney, J. T. (2005). How dynamics, management, and governance of resource deployments influence firm-level performance. Strategic Management Journal, 26(5).

Kraatz, M. S., \& Zajac, E. J. (2001). How organizational resources affect strategic change and , performance in turbulent environments: theory and evidence. Organization Science, 12(5), 632-657.

Levy, M., \& Weitz, B. (2012). Retailing Management. Diego Torres

Matthews, J. R. (2011). Assessing Organizational Effectiveness: The Role of Performance Measures. The University of Chicago Press Journal, 81(1).

Megicks, P. (2001). Competitive Strategy Types in the UK independent retail sector. Journal of Strategic Marketing, 9(4), 315-328.

Michael, L., \& Barton, A. (2004). Retail management. McGraw Hill.

Morgenstein, M., \& Strongin, H. (1992). Modern Retailing: Principles and Practices. John Willey \& Sons, Canada. 
Porter, M E. (1979). The structures within industries and company performance. Review of economics and statistics, 61(2), 214-227. Harvard Business School, Boston MA.

Porter, M. E. (1980). Competitive Strategy. New York: The Free Press.

Praharsi, Y.,Wee, H. M., Sukwadi, R., \& Padilan, M.V. (2014). Smallindependent retailers vs organized retailers: An empirical study in Indonesia economics of service industries. Journal of Retailing and Consumer Services, 21, 108-117. 